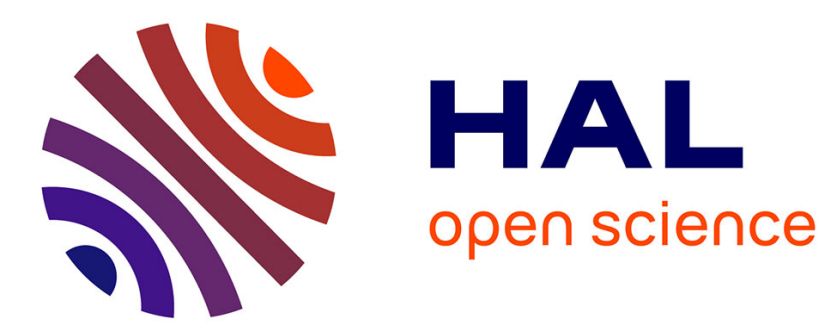

\title{
The linguistic categorization of deictic direction in Chinese - With reference to Japanese -
}

Christine Lamarre

\section{To cite this version:}

Christine Lamarre. The linguistic categorization of deictic direction in Chinese - With reference to Japanese -. Dan XU. Space in Languages of China, Springer, pp.69-97, 2008, 978-1-4020-8320-4. hal-01382316

\section{HAL Id: hal-01382316 \\ https://hal-inalco.archives-ouvertes.fr/hal-01382316}

Submitted on 16 Oct 2016

HAL is a multi-disciplinary open access archive for the deposit and dissemination of scientific research documents, whether they are published or not. The documents may come from teaching and research institutions in France or abroad, or from public or private research centers.
L'archive ouverte pluridisciplinaire HAL, est destinée au dépôt et à la diffusion de documents scientifiques de niveau recherche, publiés ou non, émanant des établissements d'enseignement et de recherche français ou étrangers, des laboratoires publics ou privés. 
Lamarre, Christine. 2008. The linguistic categorization of deictic direction in Chinese - With reference to Japanese. In Dan XU (ed.) Space in languages of China: Cross-linguistic, synchronic and diachronic perspectives. Berlin/Heidelberg/New York: Springer, pp.69-97.

\author{
THE LINGUISTIC CATEGORIZATION OF DEICTIC DIRECTION IN CHINESE \\ — WITH REFERENCE TO JAPANESE — \\ Christine Lamarre, University of Tokyo
}

\begin{abstract}
This paper discusses the linguistic categorization of deictic direction in Mandarin Chinese, with reference to Japanese. It focuses on the following question: to what extent should the prevalent bimorphemic (nondeictic + deictic) structure of Chinese directionals be linked to its typological features as a satellite-framed language? We know from other satellite-framed languages such as English, Hungarian, and Russian that this feature is not necessarily directly connected to satellite-framed patterns. Furthermore, verb-framed languages like Korean or Japanese also frequently combine deictic and non deictic paths in the same verb complex. Our conclusion is that the typological behavior of a language from the viewpoint of Talmy's typology (Verb-framed vs. Satellite-framed) has no direct bearing on its choice of bipartite encoding of paths (deictic together with nondeictic). However, these typological features likely exert an indirect influence on the strategies used by a language to combine deictic paths, nondeictic paths, and the manner or cause of motion in a same verb complex, and ultimately also on the frequency of deictic path encoding. We conclude that in order to understand why the overt linguistic expression of deictic direction is prevalent in some languages and not in others, we must take into account at least two different levels of linguistic organization, one pertaining to the syntactic devices expressing causativity and change of state, the other pertaining to the semantic devices through which languages express subjectivity.
\end{abstract}

Keywords: spatial deixis, subjectivity, motion events, directionals

\title{
Introduction
}

We discuss here the linguistic categorization of deictic direction in Mandarin Chinese, with reference to Japanese, and focus on the following question: to what extent should the prevalent bimorphemic (nondeictic + deictic) structure of Chinese directionals be linked to its typological features as a satellite-framed language?

This paper is organized as follows. First our methodology and basic concepts are introduced in Section 1. Section 2 sketches the linguistic characteristics of Chinese from the viewpoint of Talmy's framework: Chinese behaves in many ways like a satellite-framed language, which often encodes the path of motion in a verbal prefix or a verb particle, while expressing the manner or cause of motion in the verb root. However, it also frequently uses path verbs, thus behaving like a verb-framed language, just like Japanese and Korean. In Section 3, we describe Chinese path directionals (or 'satellites'), which provide two separate slots for deictic and nondeictic paths when path information is added to other semantic components of a motion event (manner, cause, etc.), as in 搬出来 bān-chu-lai 'carry out (toward speaker)'. In Section 4, we compare Chinese to a geographically close but typologically distant language: Japanese. Section 5 compares briefly Chinese with French and English.

\section{The path of motion and its linguistic categorization}

\subsection{Verbal, adverbal and adnominal encoding}

The term 'linguistic categorization' used in the title of this paper determines the way various languages code paths in a spatial motion event, and sometimes categorize it into a distinct grammatical category. When they express motion events, languages often encode the path of motion into several distinct categories. Berthele (2004) distinguishes the following types of path encoding:

i. verbal encoding: uses path verbs;

ii. adnominal encoding: combines the locative noun phrase (the Ground in

Talmy's typology) with adpositions (prepositions or postpositions);

iii. adverbal encoding: makes use of verb particles and verb affixes.

Type $\mathrm{i}$ is seen in French or Japanese, which typically use verbs to express core paths notions like 'come', 'exit', 
'descend', 'cross' etc. These languages are called 'verb-framed languages' in Talmy's typology (we call them V-languages hereafter).

Type iii corresponds to Talmy's satellite-encoding: satellites 'relate to the verb root as a dependent to a head' (Talmy 2000:102); examples include English verb particles, Russian prefixes, and Hungarian preverbs. Languages where type iii is prevalent are called 'satellite-framed languages' (hereafter S-languages).Type i. and type iii often are, to a large extent, mutually exclusive, at least in 'dominant and typical patterns'. Chinese, however, where both types are frequently used, challenges this typology (see sections 2 and 3 for details).

Languages using verbs to code core path meanings sometimes have path verbs expressing both autonomous and caused motion, as is the case with French sortir expressing both 'exit' and 'make exit', and Japanese deru and dasu expressing, respectively, autonomous and caused motion 'out' (infix - $s$ - is causativizing in Japanese). Others like Thai or Chinese lack path verbs expressing caused motion, and so have to combine them in serial verb constructions or in verbal compounds to obtain causative motion meaning.

Type ii often combines with the two other types, as is seen in languages like French (for instance in se précipiter dans la maison 'to rush in the house') which mainly encodes path into verbs, and in languages like Hungarian (ház- $\underline{b a}$ [house-into] 'into the house'), which typically encodes path into preverbs. In Chinese, a language with a split type of encoding that allows the use of Type $\mathrm{i}$ and Type iii, adnominal encoding is observed too, ex. 从屋里 cóng $w \bar{u}$-li [from room-inside] 'from inside the room', which includes both a preposition 'from' and a postposition 'inside of'.

As deictic path is expressed much more often through satellites or verbs than through prepositional phrases (hereafter PPs) in the languages we investigated, we focus here on types i and iii, the two categories which do not depend on the overt expression of the Ground Noun in the clause. We sometimes use the English adverbs 'hither' and 'thither' to translate directionals marking, respectively, motion towards and away from the speaker. However we use English verbs 'come' and 'go' to gloss Chinese deictic directionals in the examples, to show their close connection with deictic verbs. In the discussion, we refer to deictic verbs or directionals marking the motion towards the speaker as venitive, and to verbs or directionals marking a motion away from the speaker as andative verbs or directionals.

\subsection{S-languages and V-languages, deictic and nondeictic directionals}

Talmy $(1985,2000)$ grouped languages according to the way they package the semantic components of a motion event into various linguistic forms. The path categorization parameter is the term most relevant to our present discussion. Path in a motion event, as defined by Talmy (2000:25), is the path followed by the Figure object with respect to the ground object.

We give here special significance to whether the syntactic slot used for deictic paths is distinct from the slot designed for nondeictic paths, i.e. to a possibly bipartite categorization of paths in the typical expression of a motion event. A closer look at languages which grammaticalize path into a closed-class category (S-languages) shows that some of them, like Slavic languages (Russian, Polish) and Hungarian, can affix only one prefix (or satellite) to the verb root. This is not the case in Chinese, which belongs to the group of languages allowing several path satellites to be affixed to a verb root. These path satellites, often called 'directionals' or 'directional complements' in the literature, may be apportioned among various subsets, usually appearing in distinct syntactic slots, which correspond to various semantic and cognitive categories. Craig (1993:24) noticed for Jakaltek (a Mayan language spoken in the Chiapas and in Guatemala) that deictic directionals were assigned the most external slot when several directionals were fixed to the verb root: 

(1) a. ten-ik-toj
vs.
hold-in-thither
'push into away from speaker'
b. $\quad$ ten-il-tij
hold-out-hither
'pull out toward speaker'

German and Chinese also converge in assigning the deictic satellite the most external position, as illustrated in examples (2) and (3) ${ }^{1}$ :
(2) a. hin-aus-werfen
thither-out-throw
'throw out away from speaker'
b. her-aus-tragen
hither-out-carry
'carry out toward speaker'
(3) a. 扔出去
rēng-chu-qu
throw-exit-thither
'throw out away from speaker'
b. 搬出来
bān-chu-lai
carry-exit-hither
'carry out toward speaker'

In Lolovoli (an Oceanic language spoken in N.E. Ambae), deictic directionals and geographic directionals ("motion across / on the level'; 'motion up / landward'; 'motion down / seaward') are combined to form a set of nine directional verbs. These directionals combine with manner verbs to describe the direction of movement that is concurrent with the action expressed by the verb, and form verb complexes such as rororo hamai 'creep up toward the speaker' or soi hivo 'fall down away from the speaker'. The three deictic path elements are: 'away (from deictic centre)'; 'towards deictic centre'; 'towards addressee, or past/future deictic centre' (see Ross 2004, Hyslop 2001: $199-229 ; 292 ; 295-98)$.

Let us now look in detail at the Chinese twofold encoding of spatial paths, deictic and nondeictic. Chinese directionals are usually called 'directional complements', as they follow a verb to indicate the direction of the action, and share many features with the verbal items following a verb to indicate the result of the action (the 'resultative complements'). Interestingly, the combinatory possibilities of nondeictic and deictic directionals are the formal criteria generally adopted in grammar books to define the grammatical category of path directionals. Table 1 lists the main path satellites (or directionals), to show how deictic and nondeictic items combine. Symbol $\varnothing$ indicates zero. $\mathrm{P}_{\mathrm{d}}$ stands for 'deictic path', $\mathrm{P}_{\mathrm{nd}}$ for 'nondeictic path', and $\mathrm{NP}_{\mathrm{LOC}}$ for the Locative or Ground Noun Phrase (the reference of the motion). There are 9 core members of the grammatical category of path satellites (usually called 'directional complements'), on which everyone agrees, 7 nondeictic and 2 deictic.

Table 1: Standard Mandarin simple and bipartite path satellites

\begin{tabular}{|c|c|c|c|c|c|c|c|c|c|}
\hline$\frac{P_{n d}}{P_{d}}$ & zero $\varnothing$ & $\begin{array}{c}\text { up } \\
\text { shang } *\end{array}$ & $\begin{array}{l}\text { up } \\
q i^{*}\end{array}$ & $\begin{array}{c}\text { down, off } \\
x i a \\
\end{array}$ & $\begin{array}{l}\text { in } \\
\text { jin }\end{array}$ & $\begin{array}{l}\text { out } \\
\text { chu }\end{array}$ & $\begin{array}{c}\text { back } \\
\text { hui }\end{array}$ & $\begin{array}{l}\text { over, past, through } \\
\text { guo }\end{array}$ & $\begin{array}{c}\text { to } \\
\text { dao }^{* *}\end{array}$ \\
\hline $\begin{array}{c}\text { zero } \\
\varnothing\end{array}$ & $\varnothing$ & $\begin{array}{c}\text { 上 } \\
\text { shang }\end{array}$ & $\begin{array}{r}\text { 起 } \\
q i\end{array}$ & $\begin{array}{c}\text { 下 } \\
x i a\end{array}$ & $\begin{array}{l}\text { 进 } \\
\text { jin }\end{array}$ & $\begin{array}{l}\text { 出 } \\
c h u\end{array}$ & $\begin{array}{l}\text { 回 } \\
h u i\end{array}$ & $\begin{array}{c}\text { 过 } \\
\text { guo }\end{array}$ & $\begin{array}{l}\text { 到 } \\
\text { dao }\end{array}$ \\
\hline $\begin{array}{c}\text { lai } \\
\text { hither }\end{array}$ & $\begin{array}{l}\text { 来 } \\
\text { lai }\end{array}$ & $\begin{array}{c}\text { 上来 } \\
\text { shanglai }\end{array}$ & $\begin{array}{l}\text { 起来 } \\
\text { qilai }\end{array}$ & $\begin{array}{l}\text { 下来 } \\
\text { xialai }\end{array}$ & $\begin{array}{l}\text { 进来 } \\
\text { jinlai }\end{array}$ & $\begin{array}{l}\text { 出来 } \\
\text { chulai }\end{array}$ & $\begin{array}{l}\text { 回来 } \\
\text { huilai }\end{array}$ & $\begin{array}{l}\text { 过来 } \\
\text { guolai }\end{array}$ & $\begin{array}{l}\text { 到...来 } \\
\text { dao...lai }\end{array}$ \\
\hline $\begin{array}{l}q u \\
\text { thither }\end{array}$ & $\begin{array}{r}\text { 去 } \\
q u\end{array}$ & $\begin{array}{c}\text { 上去 } \\
\text { shangqu }\end{array}$ & I & $\begin{array}{l}\text { 下去 } \\
x i a q u\end{array}$ & $\begin{array}{l}\text { 进去 } \\
\text { jinqu }\end{array}$ & $\begin{array}{l}\text { 出去 } \\
\text { chuqu }\end{array}$ & $\begin{array}{l}\text { 回去 } \\
\text { huiqu }\end{array}$ & $\begin{array}{l}\text { 过去 } \\
\text { guoqu }\end{array}$ & $\begin{array}{l}\text { 到...去 } \\
d a o \ldots q u\end{array}$ \\
\hline $\begin{array}{c}\text { zǒu } \\
\text { away }\end{array}$ & $\begin{array}{r}\text { 走 } \\
z \check{u} u\end{array}$ & 1 & 1 & I & 1 & 1 & / & 1 & / \\
\hline
\end{tabular}

*-qi is source-oriented, used for instance in 站起来 zhànqilai 'stand up', whereas -shang is goal-oriented, used for instance in 爬上去 páshangqu 'climb up (a tree)'.

**-dao 'to' cannot combine directly with deictic directionals, and must followed by a locative phrase, like in 扔到 河里去 rēngdao héli qu 'throw into the river'.

As path verbs and path satellites are written with the same characters, Table 1 may be used to describe simple and bipartite path verbs as well. However, we must pay attention to the following points: when a path verb is used after a manner or cause verb in a verb complex, i.e. when it functions as a path satellite (or directional), it will be

\footnotetext{
${ }^{1}$ See Chao (1968:458) for a table showing the correspondence between German separable prefixes and Chinese directional complements.
} 
unstressed and lose its tonal characteristic, as for instance in 寄回来 jì-hui-lai [send-back-hither] 'send back toward the speaker' (the two last syllables do not bear any tonal marks, they are atonal syllables). When they function as path verbs, in the case of a bipartite item, the nondeictic component will bear stress, and the deictic element will be unstressed, as in 回来 huí-lai [return-hither] 'come back'. Deictic motion verbs lái and qù recover their original tonal value when used alone, as in 去 qù 'go!' We discuss path verbs in Section 2, and path satellites in Section 3.

\subsection{More on Table 1: path verbs and path satellites}

Table 1 includes three items which behave less prototypically than the core items corresponding to English verb particles 'up', 'down', 'in', 'out', 'over/through' and 'back'. In this section we comment on the irregular item -qi 'up', and on two more controversial items, -dao 'to' and -zŏu 'away', as well as on other path verbs which do not function as satellites and are not included in Table 1.

The source-oriented path verb qri 'rise' In Standard Mandarin, the deictic opposition is neutralized for the source-oriented path verb $q \check{\imath}$ 'rise', which can only combine with the venitive directional -lai, probably for cognitive reasons (note that this is not necessarily the case for other dialects). For instance, a group of children looking at a kite rising up into the sky (and going away from them, the deictic center) will use the path verb q $\check{l}$ 'rise'

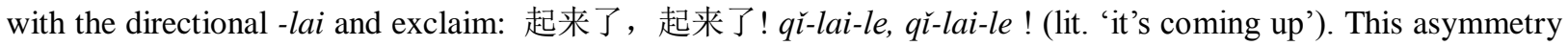
is observed when -qi appears after co-event verbs and functions as a satellite too.

The status of 到 -dao 'to' The verb 到 dào means 'to arrive'. In a postverbal position it introduces a reached goal and means 'to', its status is a controversial issue. Only -dao is unable to combine directly with the deictic directionals -lai et -qu. In Standard Mandarin it must be followed by a locative NP, like in păo-dao-xuéxiào-lai [run-to-school-come] 'run to school toward the speaker'. Patterns like păo-dao-lai [run-to-come] being ungrammatical. Some linguists argue that it should therefore be excluded from the repertory of path directionals and be treated as a postverbal preposition. Others, for instance Liu Y. (1998), consider that it shares most of its syntactic features with the nondeictic path verbs/directionals, and should be included in the list. We find the latter analysis more convincing and therefore included -dao in Table 1.

A source-oriented andative directional We noted before the possibility for deictic and nondeictic path directionals to combine is often taken as a defining feature of the category. This explains why almost no Chinese grammar acknowledges the existence of a third deictic motion verb, 走 -zŏu 'go away', nor is it included in the list of directional complements. As a source-oriented andative directional it means 'away' and is frequently used. It cannot combine with nondeictic directionals, though, and is thus generally considered as a resultative complement', not as a 'directional complement'. The opposition observed in northern Chinese between source-oriented vs. goal-oriented andatives directionals $-q u$ 'thither' and -zou 'away' is quite recent, mainly a $20^{\text {th }}$ cen. development (see Lamarre \& Liu 2001 and Lamarre 2006 for a more detailed discussion). ${ }^{2}$ Note that the andative directionals are less 'essentially deictic' than the venitive one, like in many other languages (see François 2003).

Other Path verbs We mentioned that Table 1 could be used as a list of simple and bipartite path verbs as well. But actually this would list only a small part of the path verbs used in the language, i.e. only those which function

\footnotetext{
2 The development of -zou 'away' as a source-oriented andative satellite can be seen as a strategy designed to solve the contradiction between the semantics of an andative marker with no perfectivizing effect on the verb it follows and the bounding function required from path satellites (path satellites function as the resultative predicate in a resultative compound, see Lamarre 2006 for more arguments). A comparison with languages using deictic satellites in languages in which motion path satellites are linked to boundedness (aspectual perfectivity), Hungarian and Russian, provide some hints about the ways in which a language can combine the role of perfectivization and the semantics of deictic direction. These two languages also use a preverb meaning 'away', $u$ - in Russian and $e l$ - in Hungarian. We thank here Yulia Koloskova for sharing with us her intuitions on Russian, see also Koga et al. (2006).
} 
as satellites, and can appear after verbs expressing the manner or cause of motion. Path verbs like 升 shèng 'rise', 沉 chén 'sink', 钻 zuān 'make one's way into', 退 tuì 'move back, return' or 穿 chuān 'pass through' are semantically very similar to 上 shàng 'ascend', 下 xià 'descend', 进 jìn 'enter', 回 huí 'move back' or 过 guò 'pass through', but did not grammaticalize into path satellites (or 'directional complements', as they are generally called in the literature). Even a path verb such as 掉 diào 'fall', which can function as a satellite after a manner-of-motion or a cause-of-motion verb is not generally included in the list of path satellites ${ }^{3}$ because it cannot combine with the deictic directionals -lai and -qu. Example (4) compares 掉 diào 'fall' to another semantically similar path verb 下 xià 'descend'. Both mean as a directional 'off' when they function as a satellite, (4a) and (4b) can be used to describe the motion of a hat blown off by the wind for instance. 掉 -diào cannot combine with deictic directionals, as is shown in (4c). Conversely, it frequently enters the paradigm of manner-of-motion verbs, to combine with path satellite -xia, as shown in (4d).
(4) a. 吹下来
chuī-xia-lai
b. 吹 掉
chuī-diào
blow-descend-come
blow-fall
'blow off'
'blow off'
c. * 吹掉 来
* chū -diao-lai
blow-fall-come
'blow off'
d. 掉 下来
diào-xia-lai
fall-descend-come
'fall down hither'

Talmy (2000:53-57) distinguishes between various components of the path: the deictic component, the vector component, and the conformation components. Table 1 shows that Chinese categorization makes a clear-cut distinction between deictic and nondeictic components, which are assigned different syntactic slots. The distribution of the other components is much more complex, and we will not discuss it further. We adopt here the binary opposition 'deictic' versus 'non deictic', which proves sufficient for the issues dealt with in this paper.

\subsection{Deictic path is special}

Deictic Path is a special kind of path. Talmy mentions that:

...unlike Spanish, Korean can represent both Path components concurrently in nonagentive sentences [...]

Thus Korean is a characteristically Path verb type of language, but it structurally distinguishes the Deictic component from the Conformation component of Path and accords it higher priority when both components are present. (Talmy 2000:57)

We will see that Japanese behaves very similarly to Korean: for autonomous motion, it frequently expresses deictic and nondeictic motion together, like in deteike 'go out!' or oritekita '[she/he] came down'. Furthermore, Slobin (1997:30) noted that S-languages do not necessarily work along the same pattern:

Path satellites in German encode directionality, as in English. But in addition, they encode deictic viewpoint by means of the particles hin 'thither' and her 'hither', which can combine with the directional particles. The range of possibilities is thus considerably greater than in English, allowing for expression of VIEWPOINT PERSPECTIVE along with directionality of motion. (Slobin 1997:30)

In other terms, it appears that the way a language encodes deictic paths cannot be entirely predicted by the way it encodes (nondeictic) paths in general.

Evidence of the specificity of deictic paths can be found in the fact that many typical S-languages, which are supposed to encode path into satellites rather than into verbs, do have deictic motion verbs and use them frequently.

\footnotetext{
${ }^{3}$ Chao 1968:458-467 is an exception on this matter: he treats both 掉 diào 'fall, out, off' and -zŏu 'away' as a type of directional complements which does not combine with deictic items.
} 
For instance, English typically uses satellites for nondeictic paths, but uses deictic verbs come and go instead of satellites (there are no verb particles conveying deictic direction, the adverbs hither and thither are now obsolete). This allows deictic and nondeictic paths to be combined in the same verb phrase, ex. come in. Similarly, in Hungarian, a typical S-language, none of the core path meanings ('out, in, up, down' etc.) can be encoded by a verb, except deictic paths. Hungarian uses two deictic motion verbs megy 'to go' and jön 'to come' (note that megy is sometimes translated as 'walk', and is less deictically marked than jön). Like English, Hungarian also frequently combines these deictic verbs with path satellites (in Hungarian, preverbs), as in for instance be-jön [in-come-3SG-PRE] 'she/he comes in'. Hungarian also has two deictic path preverbs 'to here/to there'. German has deictic path satellites (see ex. 2 above), but actually frequently uses deictic verbs, in spite of the fact that the andative item gehen still often retains its manner meaning of 'going by foot'.

In contrast with this, Russian and Polish have to encode both deictic and nondeictic path in prefixes. As they lack synthetic deictic motion verbs like come, they will combine a manner-of-motion verb ('move on foot', 'move by vehicle', 'fly' etc.) and a prefix expressing a deictic (or quasi-deictic) path 'toward the speaker', 'away from the speaker' instead. These structural differences make it easy to express both deictic and nondeictic paths in the same verb phrase in English, German or Hungarian (come out, go down etc.), whereas in Russian or Polish, this proves to be quite difficult, just as it is in French or in Spanish, two V-languages. Let us now turn to Chinese.

\section{Deictic motion in Chinese: the verbal encoding.}

\subsection{General facts about the encoding of paths in Chinese}

Chinese frequently uses path verbs, like French. However, like German or Jakaltek, it can encode deictic paths, nondeictic paths, and a co-event in the same verb complex (see ex. 3 above). It appears thus to be an exception to the general tendency for languages to choose between type i) of verbal encoding and type iii) of adverbal encoding. We argued in Lamarre $(2003,2007 \mathrm{a})$ that it is indeed better to treat Chinese as a 'split' type, rather as an 'equipollent' type like Thai (see Slobin 2004), for the following reasons:

1) Chinese does not randomly use verbal or adverbal encoding of paths, the V-language type of encoding is actually available only in the case of autonomous motion events; in caused motion events, paths will necessarily make use of adverbal encoding. Example (5a) shows the bipartite path verb jìnlai [enter-come] 'come in' used to answer when someone knocks at the door. Example (5b) may be used in a narrative to describe someone running into the room that holds the deictic center (or the hero in a narrative). In both cases the Figure (the moving entity) is a human being controlling his/her motion, which allows the speaker to choose between a V-language type of encoding (a path verb, type a.) and an S-language type of encoding (type b). In example (6), however, the figure is an inanimate object which relies on an external force to be moved out of a pocket or a bag, a typical instance of a caused motion event. Only an S-language type of encoding, i.e. a co-event verb 'take' followed by the path satellite 'out' (derived from the path verb 'exit') will be available in the latter case in Chinese (6b). Verbal encoding is ruled out (6a is not grammatical).
jìn-lai
enter-come
(5) a. 进来!
'Come in !'
b. 小王 跑进来 说:....
Xiăo-Wáng păo-jin-lai shuō
Young-Wang run-enter-come say
'Wang run in [toward speaker] and said:....'
(6) a. * 把 证件出来
* Bă zhèngjiàn chū-lai
OM ID-card exit-come
'Take out your identity card'
b. 把 证件 拿出来!
Bă zhèngjiàn ná-chu-lai
OM ID-card take-exit-come

This contrasts with French and Japanese, two V-languages, which can use causative path verbs sortir and dasu 'make come/go out' (cf. French: sortez vos papiers [exit ${ }_{\mathrm{CAus}}$-IMP your papers], Japanese: mibunshoo wo dase 


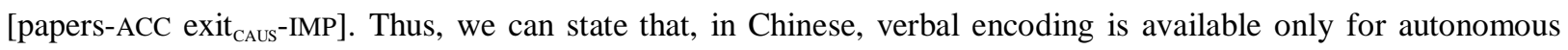
motion events, whereas adverbal encoding (an S-language type of strategy) is the only type of encoding valid both for autonomous and caused motion events. According to Talmy (2000:64-66), similar 'split patterns' also exist in Tzeltal, a Mayan language, and in Emai, a Niger-Congo language.

2) Chinese is likely to have been a V-language in its early stages and shows a drift towards an adverbal type of encoding (see Talmy 2000:118, Lamarre 2003, and also Peyraube 2006 and D. Xu 2006:146-188 for a discussion of historical data). This reminds us of the way an S-language like Latin evolved into Romance V-languages, leaving some fossilized patterns in French like path-encoding prefixes (see Kopecka 2004 and 2006). It is therefore more enlightening to treat Chinese as a language exhibiting split encoding, to grasp its historical and dialectal variation, rather than to classify it into a third category of 'equipollent languages'.

In the case of autonomous motion events, when both patterns are available, functional and stylistic factors appear to weigh heavily on the strategy used to make the choice. If we compare dialogues taken from TV series and literary texts including descriptions, we find that V-language patterns like (5a) are overwhelmingly prevalent in dialogues (more than 9/10), whereas the proportion of V-language patterns and S-language patterns is much closer to 50/50 in literary corpora. Literary texts use more co-event verbs for descriptive purposes. We will see in Section 4 that the distinction between autonomous and caused motion is also crucial to understand the differences between Chinese and Japanese when it comes to expressing deictic direction.

\subsection{Path verbs tend in Standard Chinese to be bimorphemic}

We stated above that when the figure is moving on its own and has control over its motion (what we call 'autonomous motion events'), Chinese may encode the path either in the main verb, like a V-language, or in a path satellite (or directional), like an S-language. Mandarin Chinese path verbs frequently take the form of a bipartite verb where a nondeictic element combines with a deictic one. Simple nondeictic path verbs may also be used when they are followed by a locative noun phrase indicating the goal, route, or sometimes also the source of the motion. This constraint can be understood as follows: both the locative NP and the deictic directional function as a kind of reference to the path of motion, an objective one for the former, a subjective one in case of the latter.

Table 2 shows the proportion of clauses with and without deictic directionals for four nondeictic path verbs, 'exit', 'enter', 'cross, go/come over' and 'return', in a spoken corpus ( 7.5 hours of dialogues taken from the TV series Married for ten years). In this table and hereafter, $\mathrm{V}_{\mathrm{co}}$ stands for 'co-event verb', the verb expressing the manner or the cause of the motion (the term 'co-event verb' is borrowed from Talmy 2000). $P_{d}$ stands for 'deictic path' and $P_{n d}$ for 'nondeictic path'. $\mathrm{NP}_{\mathrm{Loc}}$ stands for the Locative (or Ground) NP used as the reference for the motion.

Table 2: Four nondeictic path verbs with/without deictic directionals (dialogues)

\begin{tabular}{|l|c|c|c|c|l|}
\hline Followed or not by a locative NP & \multicolumn{2}{|c|}{ yes } & \multicolumn{2}{|c|}{ no } & total \\
\hline With or without deictic directionals -lai/-qu & without & with & without & with & \\
\hline 'enter' 进 jìn & 8 & 0 & 4 & 23 & 35 \\
\hline 'exit' 出 chū & 2 & 0 & 0 & 43 & 45 \\
\hline 'cross, come/go over' 过 guò & 0 & 0 & 0 & 38 & 38 \\
\hline 'return' 回 huí & 24 & 4 & 8 & 160 & 196 \\
\hline total & 34 & 4 & 12 & 264 & 314 \\
\hline
\end{tabular}

Table 2 shows the prevalence of the bipartite pattern [nondeictic path + deictic path], especially when no locative NP follows (264/276, i.e. more than 95\%). If we look into the details of the data, we can observe that the relatively low usage of deictic directionals for 'enter' and 'return' is due to the high frequency with which quasi-lexicalized compounds are used, where the locative NP is the object of the path verb, like 回家 huí-jiā [return-home] 'return

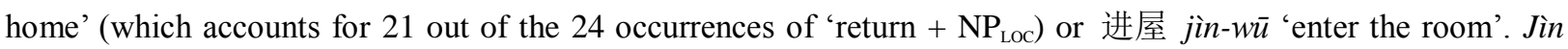


'enter' do not require a deictic directional in the disyllabic compound qǐngjìn 'please get in'. Huí 'return' may be used alone, not guò 'cross, go/come over'. Literary corpora show the same tendency.

This can be seen as reflecting a lexicalization pattern, path verbs tending to be lexicalized into disyllabic items which include a kind of objective or subjective reference as their second syllable ${ }^{4}$. We will see in section 3 that this holds for path directionals too.

\subsection{Synthetic or analytic deictic motion verbs}

It is well known that deictic paths may be lexicalized into the verb when combined with other meanings, for instance in the transitive English verbs bring and take (see Fillmore 1997:82-102 and Talmy 2000:161). French equivalents apporter / emporter and amener / emmener show the non-dominant (and already fossilized) pattern of path prefixes added to a verb root (see Kopecka 2006). These verbs incorporate the manner or motion and some kind of deictic information. Chinese equivalents 拿来 ná-lai [take-come], 拿去 ná-qu [take-go] and 拿走 ná-zŏu [take-away], as well as Japanese equivalents mottekuru [take-te-come] / motteiku [take-te-go], will also be 'analytic', i.e. bimorphemic (see Uehara 2006), they can be decomposed into a deictic motion element at least partly similar to deictic verbs 'come' (lái and kuru) and 'go' (qù and iku), and a co-event verb (ná and motsu) meaning 'take/hold in the hand'.

In Chinese, 'basic' deictic motion verbs lái and qù also show an 'analytic' variant. Northern and central Chinese dialects often use an analytic type of encoding to express the deictic motion to a goal, by combining the semantically bleached path verb shàng 'ascend' or dào 'arrive' followed by the goal NP, then by the deictic directionals -lai/qu'. In this case these verbs loose their original meaning, shàng no longer conveys any motion upwards, and dào includes the motion before the 'arrival' instead of profiling the arrival itself, both just mean 'move to'. For instance, our language consultant from Jizhou (Hebei province, a northern dialect close to Standard Mandarin) was reluctant to use the synthetic pattern, and preferred shàng to dào as the neutral verb of motion in the analytic pattern. In Heyang and Yongshou, two Mandarin dialects spoken in Shaanxi, the synthetic encoding pattern is not used either but dào is preferred in the analytic pattern (see Tang and Lamarre, 2007). However, more conservative southern Sinitic languages such as Cantonese and Taiwanese use synthetic motion verbs cognate to Mandarin lái and qù, followed by the goal locative NP instead (the analytic pattern is not accepted, see D. Liu 2000 and Liu's contribution in this volume for a discussion on Cantonese vs. Beijing and Shanghai). Standard Mandarin, the national koine, uses both northern (analytic) and southern (synthetic) patterns indifferently, and uses both shàng and dào:

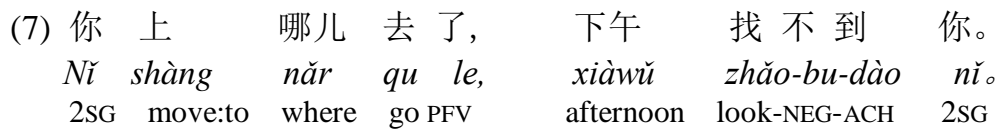

'Where have you been? This afternoon I couldn't find you.' [Ten years, 3]

(8) 咱们 现在 去 哪儿? [Ten years, 8]

Zánmen xiànzài qù năr

1PL now go where

'Where are we going now?' (asked by the driver to his boss)

\footnotetext{
${ }^{4}$ Mandarin Chinese bipartite path verbs like jìn-qu [enter-go] 'go in' are usually analyzed as Verb-Result compounds of the same syntactic nature as directional compounds (formed by a co-event verb and a path directional) like rēng-jin-qu [throw-enter-go]. Both types of compounds can be split by the insertion of a negation to express impossibility, ex. jin-bu-qù [enter-NEG-go] 'cannot go in' and rēng-bu-jìn-qù [throw-NEG -enter-go] 'cannot throw in'. However, it must be noted that some dialects do not allow such insertions in the former case (See Tang \& Lamarre, 2007). Besides, verbs like jìn-qu 'go in' do not exhibit some of the other features characterizing resultative compounds, for instance they can be negated by bù and not only by méi. We believe that these path verbs are better analyzed as lexicalized bimorphemic verbs rather than resultative compounds.

5 These analytic forms are often given another treatment in many grammar books, i.e. are considered as the combination of the preposition dào and a deictic motion verb. This treatment is problematic, though: dào would be the only preposition that can combine only with the two deictic verbs 'come' and 'go'.
} 
The analytic variant of the 'basic deictic verbs' 'come' and 'go' found in Northern Chinese reminds us of that used in Longgu (an Oceanic, Austronesian language spoken on Guadalcanal, Solomon Islands), as described in Wilkins \& Hill (1995). Wilkins \& Hill (1995) challenged the general opinion that deictic motion verbs 'come' and 'go' are lexical universals which manifest a universal deictic opposition. In Longgu, 'come' and 'go' are expressed through the combination of a deictically neutral motion verb la 'travel, move along a path', and of directional particles -mai 'hither' and -hou 'away from here'. Chinese, more than Japanese, provides evidence to support Wilkins and Hill's point of view. We consider the 'analytic pattern' described above for Northern and central dialects (as well as Standard Mandarin where it coexists with the synthetic pattern) as reflecting the same bimorphemic pattern of lexicalization we described in the preceding section 2.2. In the case of deictic motion verbs, the first morpheme or 'nondeictic path' gets bleached and does not express a concrete nondeictic path any longer This allows deictic and nondeictic path verbs to be unified into a bimorphemic structure and may be seen as some kind of leveling (see Lamarre 2007b).

The opposition between a source-oriented 走 zǒu 'walk, go away, leave', vs. a goal-oriented andative qù observed in Northern Chinese is another piece of evidence in favor of Wilkins and Hill's conclusion: deictic motion verbs 'come' and 'go' are not basic, and their lexical semantics vary to the extent that no 'universal' can be safely assumed. In Chinese, the venitive verb lái has been extremely stable, but the andative verb shows huge variation both in history and in dialects. One parameter of this variation is that of source-oriented vs. goal-oriented andative motion ${ }^{6}$.

\section{Deictic direction in Chinese: the adverbal encoding}

\subsection{Prototypical Path Satellites are bimorphemic}

Table 1 listed both simple and bipartite deictic and nondeictic path directionals, which suggests that speakers are free to express only deictic, or only nondeictic paths. However, we showed in section 2.2 and 2.3 that there is a strong tendency for path verbs to be bimorphemic, i.e. to be composed of a nondeictic and a deictic element. This tendency exists when path verbs function as satellite (or directional) too. Data show that although clauses where the nondeictic directional is used alone (like $\left[\mathrm{V}_{\mathrm{co}}+\mathrm{P}_{\mathrm{nd}}+\right.$ zero]) or clauses where the deictic directional is used without the nondeictic one (like $\left[\mathrm{V}_{\mathrm{co}}+\right.$ zero $\left.+\mathrm{P}_{\mathrm{d}}\right]$ ) are not prohibited; the prototypical path satellite, like the prototypical path verb, is in Chinese bipartite, and combines a nondeictic and a deictic element, the verb phrase taking the form $\left[\mathrm{V}_{\mathrm{co}}+\mathrm{P}_{\mathrm{nd}}+\mathrm{P}_{\mathrm{d}}\right]$. We describe constraints on monomorphemic path satellites in the next sections.

\subsection{Nondeictic path directionals tend to be followed by deictic directionals}

The tightest constraint is observed for combinations of the type $\left[\mathrm{V}_{\mathrm{co}}+\mathrm{P}_{\mathrm{nd}}\right]$. Previous studies (Ju 1992, Y. Liu 1998:36-8, Qi 1998:180) noted that unless the verb is followed by a locative NP (or by another NP like the patient of the verb, the Figure), path directionals are usually bipartite, the deictic direction being overtly expressed. Y. Liu (1998:36) gives the following example as ungrammatical:

$$
\begin{aligned}
& \text { (9) * 下课 了, 孩子们 跑出。 } \\
& \text { xiàkè le, háizi-men păo-chu } \\
& \text { class:end PFV child-PLUR run-exit } \\
& \text { 'classes are over, the children run out' }
\end{aligned}
$$

In order to become grammatical, the verb compound ending the sentence should be extended with a deictic directional like -lai (if the speaker looks at the children from outside the classroom), i.e. păo-chu-lai [run-exit-come] 'run out toward the deictic centre'. If a noun phrase appears after the verb complex, this constraint

\footnotetext{
${ }^{6}$ The reader may consult Xu Dan's contribution in this volume for a further discussion of the historical evolution of Chinese deictic motion verbs. As for dialectal variation, in some northwestern dialects, zŏu 'go away' can be followed by a goal locative $\mathrm{NP}$ and as a path satellite may even combine with nondeictic path satellites.
} 
disappears.

Table 3 gives the relative frequency of use of non-deictic path directionals $\left(\mathrm{P}_{\mathrm{nd}}\right)$ with and without deictic path directionals $\left(\mathrm{P}_{\mathrm{d}}\right)$ in a sample of 7.5 hours of TV dialogues (128 clauses). We chose clauses which include a combination of a co-event verb and a path directional not followed by any NP. Data show that, in most of the cases, the use of a non-deictic directional also implies the expression of deictic direction. In other terms, pattern (2), $\left[\mathrm{V}_{\text {co-e }} \mathrm{P}_{\text {nd }} \mathrm{P}_{\mathrm{d}}\right]$, which uses a bimorphematic path satellite, is the most frequent. The proportion of autonomous motion and caused motion clauses is given in the brackets (autonomous / caused) ${ }^{7}$.

Table 3: Correlation in the use of non-deictic and deictic directionals (dialogues)

\begin{tabular}{|c|c|c|c|c|c|c|c|c|c|}
\hline $\begin{array}{r}P_{n d} \\
\text { pattern }\end{array}$ & $\begin{array}{l}P_{\text {nd }} \\
=\varnothing\end{array}$ & $\begin{array}{c}\text { 进 -jin } \\
\text { 'in' }\end{array}$ & $\begin{array}{l}\text { 出 -chu } \\
\text { 'out' }\end{array}$ & $\begin{array}{l}\text { 上 -shang } \\
\text { 'up'* }\end{array}$ & $\begin{array}{l}\text { 起 -qi } \\
\text { 'up'* }\end{array}$ & $\begin{array}{l}\text { 下 -xia } \\
\text { 'down' }\end{array}$ & $\begin{array}{c}\text { 过 -guo } \\
\text { 'across } \\
\text { over' }\end{array}$ & $\begin{array}{l}\text { 回 -hui } \\
\text { 'back' }\end{array}$ & total \\
\hline $\begin{array}{c}(1) \\
\mathrm{V}_{\mathrm{co}} \mathrm{P}_{\mathrm{nd}} \varnothing\end{array}$ & 1 & I & 1 & $\begin{array}{c}2 \\
(2 / 0) \\
\end{array}$ & & $10(9 / 1)$ & I & 1 & $\begin{array}{c}12 \\
(11 / 1) \\
\end{array}$ \\
\hline $\begin{array}{c}(2) \\
V_{\mathrm{co}} \mathrm{P}_{\mathrm{nd}} \mathrm{P}_{\mathrm{d}}\end{array}$ & l & $\begin{array}{c}6 \\
(2 / 4) \\
\end{array}$ & $\begin{array}{c}18 \\
(7 / 11)\end{array}$ & $\begin{array}{c}1 \\
(1 / 0)\end{array}$ & $\begin{array}{c}7 \\
(3 / 4) \\
\end{array}$ & $\begin{array}{c}7 \\
(3 / 4) \\
\end{array}$ & $\begin{array}{c}18 \\
(5 / 13)\end{array}$ & $\begin{array}{c}28 \\
(5 / 23) \\
\end{array}$ & $\begin{array}{c}85 \\
(26 / 59) \\
\end{array}$ \\
\hline $\begin{array}{c}(3) \\
\mathrm{V}_{\mathrm{co}} \varnothing \mathrm{P}_{\mathrm{d}}\end{array}$ & $\begin{array}{c}31 \\
(3 / 28) \\
\end{array}$ & 1 & 1 & 1 & 1 & 1 & 1 & 1 & $\begin{array}{c}31 \\
(3 / 28) \\
\end{array}$ \\
\hline total & 31 & 6 & 18 & 3 & 7 & 17 & 18 & 28 & $\begin{array}{c}128 \\
(40 / 88)\end{array}$ \\
\hline
\end{tabular}

* Both 起 - $q i$ and *上-shang mean 'up' but - $q i$ is used for source -oriented motion, -shang for goal -oriented motion (see Table 1).

Only two non-deictic directional items (goal-oriented 'up' and 'down') out of seven happen to combine with a co-event verb without a deictic directional (pattern $\left[\mathrm{V}_{\mathrm{co}} \mathrm{P}_{\mathrm{nd}}\right]$ ). They are used after verbs of change of posture and placement ('sit', 'kneel', 'squat', 'put down [your bag]') where the deictic opposition is less likely to operate for quite understandable semantic reasons. Other directionals, 'in', 'out', 'across/over', and the source-oriented 'up', demand the use of a following deictic directional (pattern $\left[\mathrm{V}_{c o} \mathrm{P}_{n d} \mathrm{P}_{d}\right]$ ). Thus in this sample of dialogues, $88 \%$ of the clauses including a nondeictic directional (85 out of 97) also included a deictic one, if the syntactic environment required it (no NP after the verb complex). We now know which directionals are less likely to take overt markers of deictic direction: those expressing vertical paths and where the human body does not undergo any change of position. The 31 clauses that do not include nondeictic directionals ( $\left[\mathrm{V}_{\mathrm{co}} \mathrm{P}_{\mathrm{d}}\right]$ patterns) will be discussed in the next section. Note that Table 3 only lists directionals used in their spatial meaning ${ }^{8}$.

These findings confirm an observation made by Y. Liu (1998:38): she looked at clauses that included a co-event verb followed by -shang 'up' (goal-oriented) in her (written) corpus, and found that in $97 \%$ of the 365 clauses where -shang was not followed by deictic directional -lai or - $q u$, the verb was followed by a locative or a Figure NP. On the other hand, most of the clauses using the bipartite path directional (pattern $\left[V+P_{n d}+P_{d}\right]$ ) did not include any postverbal NP, and the verbal complex appeared in the clause-final position.

The expression of deictic motion can be considered as one of the linguistic devices which express subjectivity. It is thus not surprising that dialogues should include more deictic directionals than literary descriptive texts or 'objective' news reports. Let's now compare a spoken corpus (the same TV series) to a literary corpus (which includes some dialogues too). In spoken Standard Mandarin, Figure NPs rarely appear after the verb complex, in other terms, one of the conditions that allow deictic directionals to be omitted is rarely met. Locative NPs other than goal NPs rarely appear after the verb complex too. Table 4 shows that the opposite is true in literary corpora: in many clauses describing a motion event, the locative NP or the Figure NP appears after the verb, making it easier to

\footnotetext{
${ }^{7}$ Data about - dao are not included in this table, nor in Table 4.

${ }^{8}$ It is very tricky to establish a distinction between the different uses of directionals. To avoid being to arbitrary, we made use of Y. Liu 1998's criteria. She distinguishes between a spatial use, a fulfillment use, and and an aspectual use of directionals. Although her criteria are not ideal, she gives very complete lists for each use, which are easy to refer to. Note that her 'spatial' uses include some metaphoric uses too, that we also included, so that our definition of a motion event is quite broad (for instance we include money transactions).
} 
leave deictic information covert, which fits with the 'objectivity' of written texts. The two corpora compared here are dialogues of the TV series Married for ten years ( 7.5 hours) and Chen Rong's novel At middle age. We looked at the 7 main nondeictic path directionals (-dao is excluded, like for Table 3). Three patterns were taken into account: In pattern (A) no locative or Figure NP appears after the verb complex. This is an environment which usually requires the expression of deictic direction (the verb complex is clause-final), both in written and in spoken style. In pattern (B) the nondeictic path satellite is followed by a locative NP. Pattern (C) is restricted to caused motion sentences or presentative sentences, where the nondeictic path satellite is followed by the Figure NP. (B) and $(\mathrm{C})$ are patterns which are said to allow the omission of the deictic directional.

Table 4: $\left[\mathrm{V}_{\mathrm{co}}+\mathrm{P}_{\mathrm{nd}}\right]$ compounds with and without postverbal NPs, and frequency of the expression of deictic path, in a contemporary novel and in TV dialogues ${ }^{9}$ (\% of clauses with deictic path out of the total number of clauses per pattern)

\begin{tabular}{|c|c|c|c|}
\hline $\begin{array}{l}\text { pattern: } \\
\text { (position of the locative or / and Figure NP) }\end{array}$ & $\begin{array}{l}(\mathrm{A}) \\
\mathrm{NP}_{\mathrm{LOC}} \text { and/or } \mathrm{NP}_{\text {fig }} \\
\text { covert or preverbal }\end{array}$ & $\begin{array}{c}(\mathrm{B}) \\
\mathrm{V}_{\mathrm{co}} \mathrm{P}_{\mathrm{nd}}+\mathrm{NP}_{\mathrm{LOC}}\end{array}$ & $\begin{array}{c}(\mathrm{C}) \\
\mathrm{V}_{\mathrm{co}} \mathrm{P}_{\mathrm{nd}}+\mathrm{NP}_{\mathrm{FIG}}\end{array}$ \\
\hline TV dialogues & 97 & 4 & 2 \\
\hline$\%$ of expressed deictic path & $85(88 \%)$ & $1(25 \%)$ & $2(100 \%)$ \\
\hline literary corpus & 102 & 51 & 69 \\
\hline$\%$ of expressed deictic path & $81(80 \%)$ & $5(10 \%)$ & $27(40 \%)$ \\
\hline
\end{tabular}

For Pattern (A), in the literary corpus, -xia 'down' accounted for 20 out of 21 occurrences of a nondeictic path directional without -lai or -qu, like in the dialogue corpus (see Table 3 above). As for Pattern (B) and (C), Table 4 shows that they are actually rare in dialogues, where the Figure NP usually appears before the verb when overtly expressed. Locative NPs mainly occur after -dao in dialogues, not often after the other path verbs. We mentioned earlier that the goal marker -dao requires to be followed by a goal locative NP, and this can account for some specific behavior concerning its lexicalization into a bimorphemic path verb. Thus Table 4 shows that even if we take into account these patterns where NPs appear after the verb complex, the general tendency shown in Table 3 is not altered for spoken data. Let us give examples of some of these patterns. Example (10) illustrates the most frequent pattern in the case when the figure is overtly expressed (pattern A): it is put before the verb with the help of the object marker (OM) bă:

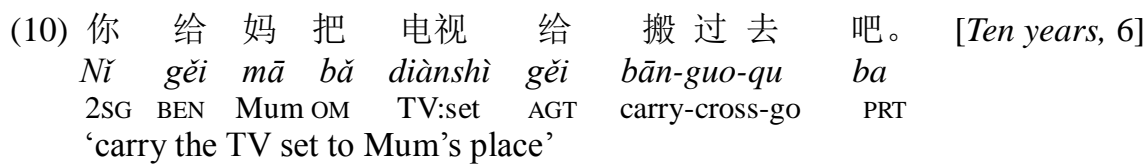

In example (11) the Figure is covert but easily inferred from the situation (Pattern A): the speaker refers to a carpet she brought back from Australia and sold to the hearers. The locative NP expressing the source of the motion is expressed through a preverbal PP, showing the pattern [Preposition $\left.+\mathrm{NP}_{\mathrm{Loc}}+\mathrm{V}_{\text {co-e }}+\mathrm{P}_{\text {nd }}+\mathrm{P}_{\mathrm{d}}\right]$. The co-event verb is a dummy verb (see Talmy 2000:284-5).

\section{(11) 我 呢, 从那边弄回来也挺 不容易 的。[Ten years, 2] wǒ ne cóng nèibian nòng-hui-lai yě tǐng bù róngyì de 1SGPRT from there get-return-come also very NEG easy PRT 'I had quite a lot of trouble to bring it back from there'}

The following examples illustrate pattern (B), $\left[\mathrm{V}_{\text {co-e }}+\mathrm{P}_{\mathrm{nd}}+\mathrm{NP}_{\mathrm{Loc}}\right]$, where a locative NP appears after the verb and deictic direction may be omitted. The deictic directional is added in example (12), not in example (13), a

\footnotetext{
9 Table 4 shows the proportion of clauses where a deictic path is expressed when a nondeictic path is also expressed, and thus does not include constructions without nondeictic path directionals like Tã jìle yì bāo cháyè laile 'he sent a pack of tea [hither]' (Married ten Years). Table 4 takes account of both autonomous and caused motion events, for the 7 nondeictic core path directionals (-dao excluded).
} 
descriptive sentence in a narrative.

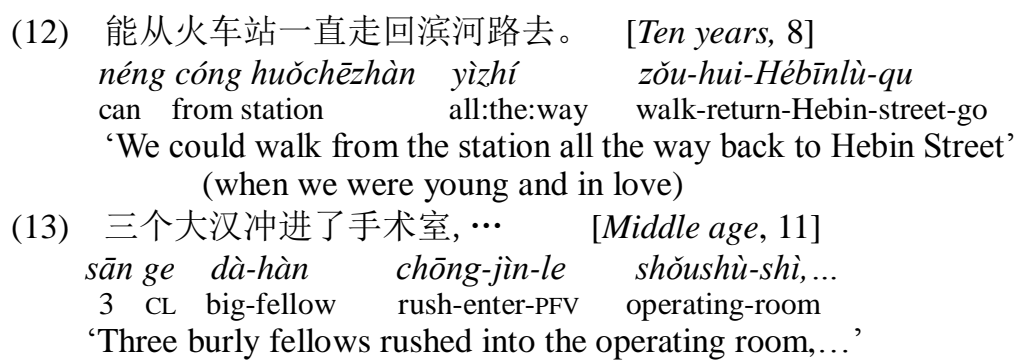

Example (14) illustrates pattern (C), $\left[\mathrm{V}_{\text {co-e }}+\mathrm{P}_{\mathrm{nd}}+\mathrm{NP}_{\mathrm{FIG}}\right]$, where the figure of a caused motion event appears after the verb complex. Patterns (B) and (C) are widespread in the written style, but actually quite rare in dialogues.

(15) 她叹了口气，从抽屉里拿出点零钱说: ... [Middle age, 8]

tā tàn-le kǒu qì cóng chōuti-li ná-chu diăn língqián shuō

3SG heave-PRF CLF sigh, from drawer-inside take-exit some small.change say

'She sighed, took a few coins out of the drawer, and said...'

\subsection{Deictic directionals tend to be preceded by nondeictic directionals}

As for constraints on $\left[\mathrm{V}_{\mathrm{co}}+\mathrm{P}_{\mathrm{d}}\right]$ (i.e. pattern (3) in Table 3, where the nondeictic path element does not appear), our data show that, in dialogues, this pattern is mainly used to encode caused motion events (the proportion was of 3 autonomous motion clauses vs. 28 caused motion clauses in Table 3). In autonomous motion events, where the co-event verb expresses the manner of motion, andative directional - qu is rare. Lamarre 2005 argues that manner-of-motion verbs like 'run' or 'walk' combined with the andative verb qù depart in many ways from typical directional compounds, and notes that such patterns are typical of the written style (see also Liu Y. 1998:36, and Xu Dan's contribution in this volume). This is confirmed by our dialogue data, where the 3 autonomous motion clauses illustrating pattern (3) all use the venitive directional -lái. On the other hand, in the novel At middle age, 35 of the 50 clauses following this pattern describe autonomous motion events, and 13 out of these clauses used the andative directional -qù, all were descriptive sentences in a narrative. Examples (16) and (17) illustrate the heterogeneity of pattern (3) $\left[\mathrm{V}_{\mathrm{co}}+\mathrm{P}_{\mathrm{d}}\right]$ when it comes to aspectual features and textual function. Example (16) is an imperative sentence taken from a dialogue, the speaker complains about the taste of the fish she was served and orders the waitress to call the proprietor of the restaurant, the verb-directional compound is causative. Example (17) is taken from a narrative, the PP expressing direction 'towards the ward' proves that the clause is atelic in spite of the use of a directional.

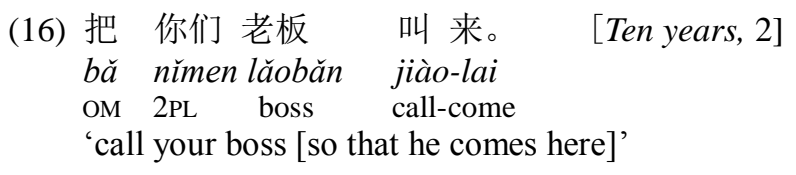

(17) 赵天辉两手插在白大补的衣兒里,

Zhào Tiānhū liăng-shǒu chā-zài bái dàguà de yīdōu-li

Zhao Tianhui two-hands insert-at white coat GEN pocket-inside

一边同孙逸民谈着，一边向病房走去。 [Middle age, 6]

yibiān tóng Sūn Yìmín tán-zhe yibiān xiàng bìngfáng zǒu-qù SIM with Sun Yimin talk-DUR SIM toward ward walk-go

'Zhao Tianhui, both hands thrust into the pockets of his white coat, was walking toward the ward while talking with Sun Yimin.

If we look at non-standard varieties of Chinese, we can observe that there are several dialects which do not allow deictic directionals to combine directly with the co-event verb (pattern (3) $\left[\mathrm{V}_{\text {co }} \mathrm{P}_{\mathrm{d}}\right]$ in Table 3), and use dummy 
elements instead to fill up the slot of the non-deictic directional. For instance, Mandarin 拿来 ná-lai [take- $\varnothing$-come] 'bring' becomes [take-dummy $\mathrm{P}_{\mathrm{nd}}$-come], with a dummy [.tə?] in Shanxi and in Shanghai, a dummy [.1॰] in Hebei, or a dummy [.to] in Shaanxi (see Lamarre \& Liu 2001, Lamarre 2002, Tang \& Lamarre 2007). We interpret this as an indirect consequence of the bimorphemic pattern of lexicalization of path verbs. In Chinese, path verbs, when they function as the resultative predicate in a resultative compound, i.e. when they function as satellites after another verb, tend to have a bounding function. In the case of bimorphemic path verbs, only the first item (the nondeictic one) carries out this syntactic function, leaving to the deictic item a mere 'directional' function. In Standard Mandarin, this is reflected by constraints on the andative directional - $q u$ 'thither', and by the development of another andative directional, -zou 'away', semantically more adapted to its bounding function. But some dialects developed a semantically bleached resultative form, used when there is no need to express a concrete nondeictic path. It enters the slot of the nondeictic path resultative and achieves this bounding role.

\subsection{Bimorphemic path satellites and Mandarin's typological characteristics}

Let's go back to our initial research question: is this tendency to express deictic path whenever nondeictic path is expressed related to the S-language encoding observed in Chinese? The answer then is apparently 'no': data (Table 2) show that even when Chinese behaves like a V-language and expresses autonomous motion events through path verbs, like in 回来 huí-lai! [return-come] 'come back!', the typical pattern is a twofold encoding [nondeictic + deictic path]. However, if we look at historical data, we can see that bipartite path verbs are far from being frequent in Classical Chinese. Cui (2005), in a comprehensive study on the evolution of Chinese path verbs from Archaic to Medieval Chinese, showed that bimorphemic path verbs of the type [nondeictic path+deictic path] are not a usual feature in Archaic Chinese (also called 'Classical Chinese'). Their number increases only from the Medieval Period (after the $3^{\text {rd }}$ cen.), following the same evolution as the resultative constructions.

To make a comparison between Classical Chinese and Modern Chinese, we surveyed samples of various Chinese texts written in Classical Chinese (Classical Chinese survived the Archaic Period as a written language), and looked at their translations into Modern Chinese. Table 5 presents data from two texts of which several translations into Modern Chinese are available, A New Account of Tales of the World (Shishuo Xinyu, $5^{\text {th }}$ cen), and 3 stories taken from Pu Songling's Strange tales of Liaozhai (end of $17^{\text {th }}$ cen.). We chose stories related to everyday-life events, preferably with dialogues where deictic motion was likely to be expressed, and checked several translations, to avoid any personal bias. The data given in Table 5 are restricted to the three high-frequency path verbs 'enter', 'exit', and 'return'. Even the most conservative translators, who avoided colloquial expressions, regularly added deictic directionals in the 51 cases when the original text used only nondeictic path verbs (the modern Chinese sentences taken into account here are those where the verb complex is not followed by any locative or Figure NP, to be consistent with the rule at work in Modern Chinese). Table 5 details the deictic directional added in the modern translation, -lai 'hither' or - $q u$ 'thither'. Please note that the same lexical item is used for 'exit' throughout the period, whereas the lexemes for 'enter' and 'return' underwent lexical replacement (the item at the right of the arrow is the modern lexeme). In the case of 'return', several lexemes coexisted in Classical Chinese, only huí is used now as directional complement in Standard Chinese ${ }^{10}$.

We can thus conclude that even if we cannot find any real evidence for a causal link between the bipartite structure and the S-language tendency, the typological change towards an S-language probably occurred hand-in-hand with the evolution of path verbs towards a bipartite structure [nondeictic+deictic]. Besides, this development is observed only for a small subset of the nondeictic path verbs used in Chinese, precisely those which express the core path

\footnotetext{
${ }^{10}$ For 12 tokens out of 51, the modern translation also added a manner verb like 'walk' (the most frequent addition), 'run', and 'flow' before the path elements. That is, in modern Chinese a S-language or adverbal type of encoding [co-event verb + path satellite] was used to translate Classical Chinese path verbs. This reflects the shift from a V-language to a S-language that occurred in Chinese.
} 
schematic meanings and grammaticalize into path satellites. Other path verbs (for instance those evoked in 1.3) do not show this lexicalization pattern.

Table 5: Deictic direction added to nondeictic path verbs in modern translations of classical texts

\begin{tabular}{|c|c|c|c|c|}
\hline & $\begin{array}{c}\text { 入 } r u ̀ ~ \\
\text { 'enter' }\end{array}$ & $\begin{array}{l}\text { 出 } c h \bar{u} \\
\text { 'exit' }\end{array}$ & $\begin{array}{c}\text { 还 huán, 归 guī, } \\
\text { 反/返 făn } \rightarrow \text { 回 huí 'return' }\end{array}$ & total \\
\hline Shishuо Хіпуи & 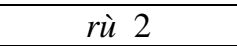 & $\operatorname{ch} \bar{u} 8$ & \begin{tabular}{l|l|l|} 
huán 8 & gū 2 & făn 4
\end{tabular} & 24 \\
\hline Modern Chinese & $\begin{array}{l}\text { jìn-lai } 1 \\
\text { jìn-qu } 1\end{array}$ & $\begin{array}{l}\text { chü-lai } 7 \\
\text { chü-qu } 1\end{array}$ & $\begin{array}{l}\text { huí-lai } 8 \\
\text { huí-qu } 6\end{array}$ & \\
\hline Liaozhai & rù 8 & $\operatorname{ch} \bar{u} 9$ & făn 2 & 27 \\
\hline Modern Chinese & $\begin{array}{l}\text { jìn-lai } 1 \\
\text { jìn-qu } 7\end{array}$ & $\begin{array}{l}\text { chü-lai } 7 \\
\text { chū-qu } 2\end{array}$ & $\begin{array}{l}\text { huí-lai } 6 \\
\text { huí-qu } 4\end{array}$ & \\
\hline
\end{tabular}

Another factor to be taken into account is the tendency for monosyllabic words to develop into disyllabic words widely attested in the history of Chinese lexicon.

To sum up Section 3, directionals in Standard Mandarin tend to exhibit a bipartite structure [nondeictic + deictic], which is further attested by various constraints weighing on patterns using non-deictic directionals without deictic ones, or, at a lesser extent, deictic directionals without nondeictic ones. These constraints are especially strict in the colloquial style, whereas the written language is less rigid. All this points to a high categorization (a high degree of grammaticalization) of path directionals: when a directional is used, it must be taken from a closed-class category of less than 10 elements, and likely takes the shape of a twofold directional $\left[D_{n d}+D_{d}\right]$. Standard Mandarin's looser rules are probably the result of koineization, and maybe also reflect the fact that as a written language it retains fossilized structures from older layers of the language, and maybe even artificial structures coined more recently.

\section{The coding of path in Japanese}

\subsection{Japanese complex predicates and the expression of path}

Japanese is a V-language which differs from V-languages like French or Spanish in its wide use of verb complexes. The behavior noted by Talmy (2000:57) for Korean (see our quotation in 1.4 above) basically applies to Japanese too: characteristically, Japanese is a Path verb type of language, but structurally it distinguishes the Deictic component from the Conformation component of Path. Let us give below a more detailed account of these various verbs complexes.

The first type of complex predicate is obtained through the combination of two verbal elements at the lexical level, to create compound verbs like kake-agar-u [run-ascend-NPAST] 'run up', suberi-de-ru [slip-exit-NPAST] 'slip out', and $o$ shi-kom- $u$ [push-enter ${ }_{\mathrm{CAus}}$ ] 'throw in'. (See Matsumoto 1996:237-81 for an account in English of the semantic relationship between the two components). The first two examples denote autonomous motion, the third example caused motion. Note that this compounding process is not fully productive, and many combinations of manner/cause and path possible or frequent in Chinese or English are left out: kake-agar- $u$ 'run up' is attested, but not aruki-agar-u 'walk up' (see Matsumoto 1996:277). This type of compound verb is not of direct interest to us here, because such verbs usually only combine manner or cause with nondeictic paths, not with deictic path (*kake-ik-u / *hashiri-ik-u [run-go-NPAST] 'go running', *komi-ik-u / *hairi-ik-u [enter-go-NPAST] 'go in'). Note also that some path and manner verbs have special verb roots used only in verb compounds. Thus in the following pairs: -kom- $u$ vs. hair- $u$ 'enter', kake- vs. hashir- $u$ 'run', the former are bound forms, the latter are free forms.

The other type of verb complex, involving $t e$-linkage, occurs at the syntactic level, and is called by Shibatani (2003) the 'conjunctive compound construction'. All verb complexes involving a deictic path component fall into this type. Here is a list of the possible combinations involving deictic direction: 
a) [nondeictic path verb expressing autonomous motion $+t e+$ deictic path verb]:

de-te-it-ta (exit-te-go-PAST) 'go out'; hait-te-kur-u (enter-te-come-NPAST) 'come in'; modot-te-kur-u (return-te-come-NPAST) 'come back'; agat-te-ik-u (ascend-te-go-NPAST) 'go up'

b) $[$ manner verb + te + deictic path verb]:

hashit-te-ik-u [run-te-go-NPAST] 'go running'; oyoi-de-ki-ta [swim-te-come-PAST] '(I) came swimming'

c) [compound verb (co-event verb + nondeictic path) + te + deictic path verb]:

kake-kon-de-ku-ru [run-enter-te-come-NPAST] 'run in toward the speaker'

d) [co-event verb + te + nondeictic path verb + te + deictic path verb]:

hasit-te- modot-te-kuru [run-te-return-come-te-NPAST] 'run back toward the speaker'

Matsumoto (1996) calls type b) a 'participial complex motion predicate', where the co-event verb expresses the manner of motion ('run') or the accompanying event of motion ('carry') (see also Tanaka and Matsumoto 1997).

\subsection{The expression of deictic paths in autonomous and caused motion events}

As was noted by Shibatani (2003), although nondeictic motion may be used without deictic direction being expressed (for example in kanojo-wa heya-kara de-ta [she-TOP room-from exit-PAST] 'she got out of the room') in casual dialogue, the speaker often expresses both types of path as in pattern a), (heya kara de-te-kita [room-from exit-come-PAST] 'came out from the room'), otherwise the sentence is felt as lacking an important information: the speaker's location when the event occurred. The same has been noted for Korean, where this tendency is said to be even stronger than in Japanese (see Fukami 1999).

Japanese is known for its various devices expressing subjectivity, and spatial deixis is just one of the ways it is expressed, together with the verbs of 'giving' and 'receiving'; person deixis is underdeveloped. Verbs of coming and going -iku and -kuru, in their basic directional - spatial - use, behave as the head of these complex predicates, bearing the marks of tense, passivation etc. (see Matsumoto 1996, note that Shibatani 2003 argues that even in type b) the manner verb and the deictic motion verb carry the same semantic weight). Two points are to be noted here, which bear some importance in understanding the difference with Chinese.

First, the deictic verb, the last item of the verb complex, shares its subject with the preceding verbs, and may only express the motion of the subject of the first verb.

Second, in each of the four cases, a) to d), the interpretation of -kuru or -iku as the deictic direction of a motion event is triggered by the semantics of the first predicate. That is to say, whenever the semantics of the first predicate blocks this interpretation of a 'simultaneous motion', when for instance the first predicate is an action verb like 'eat' or 'play', the semantic relationship between the predicates is interpreted as being sequential, ex. tabe-te-ik-u [eat-te-come-NPAST] 'eat and then go' or ason-de-ku-ru [play-te-come-NPAST]'play (somewhere) before coming' etc.

e) In complex predicates where the first verb is a causative path verb, the deictic direction is interpreted as the

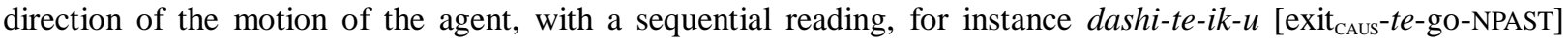
means 'take something out and go (somewhere)' and not 'take something out away from the speaker'.

f) When the first verb expresses an action like 'take' or 'carry', this difference is blurred by the fact that the agent and the patient move conjointly: hakon-de-ku-ru [carry-te-come- NPAST] means 'to carry and come', but as the carrier and the carried object move together, the situations in which such verb complexes are used are roughly similar to the situations where Chinese uses 搬来 bān-lai [carry-come] (see example (21) below). The semantic mismatch becomes obvious for verbs like 'hit', 'throw', 'kick' or 'send (a letter)', in which the agent does not move together with the patient. For instance $o k u t-t e-i k-u$ [send-te-go-NPAST] can only mean 'send (a letter etc.) and then 
go (somewhere)', and never 'send a letter away from the speaker', whereas in Chinese 寄去 jìqu [send-go] precisely means 'send a letter away from the speaker'.

g) As a result, when Chinese combines a causative co-event verb with both nondeictic and deictic paths, there can be no Japanese equivalent. 'Take out (your purse from your bag)' will be expressed in Chinese with the verbal complex 拿出来 ná-chu-lai [take-exit-come], but the parallel verb complex in Japanese tori-dashi-te-ku-ru [take-exit ${ }_{\mathrm{CAUS}}-t e$-come- NPAST] will imply that the agent moves towards the speaker after having taken out the purse from the bag (see ex. 23 below).

Let's first look at a few sentences expressing autonomous motion, where the encoding of deictic motion coincides in Chinese and in Japanese. Pattern a) (ex. 18) is similar to a Chinese nondeictic path verb followed by a deictic path element:

(18) [Jap.] hait-te-ik-u enter-te-go-NPAST

[Ch.] jìn-qu enter-go 'go in'

de-te-ku-ru
exit-te-come- NPAST
chū-lai
exit-come
'come out'

modot-te-ku-ru

return-te-come- NPAST

huí-lai

return-come

'come back'

Patterns b), c) and d) have Chinese equivalents too, see examples (19) and (20):

(19) [Jap.] 流て行く $\begin{gathered}\text { nagare-te-ik- } u= \\ \text { flow-te-go-NPAST }\end{gathered}=$ [Ch.] 流去 $\begin{gathered}\text { liú-qù } \\ \text { flow-go }\end{gathered} \quad$ (written style) 'go flowing', '[water] flows away toward some place'

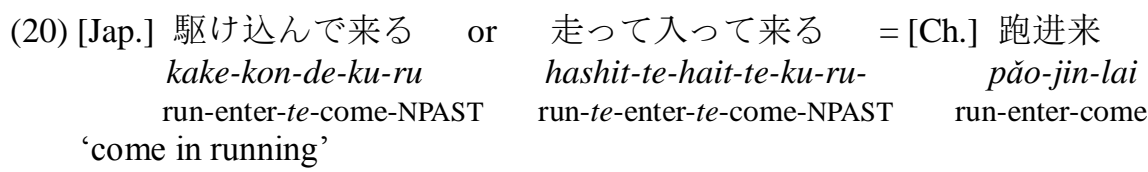

In the case of caused motion, however, Japanese and Chinese widely diverge. This is not obvious at first sight, because in everyday life, quite a few caused motion events where the agent pushes and carries things imply the joint motion of the agent (the subject) and the object patient of the cause verb, as in example (21) below. Chinese ná and Japanese motsu mean 'take/hold in the hand':

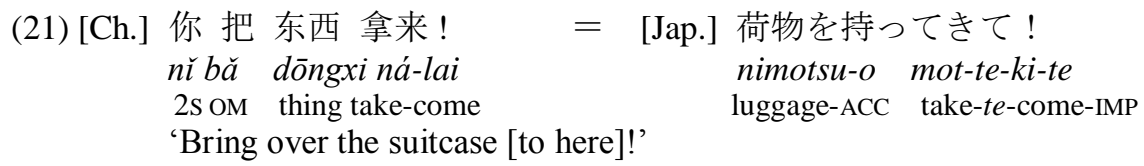

However, as in Japanese the head of the verb complex is the final verb 'come/go', the deictic motion expresses the motion of the subject. When the subject (the agent) and the object (the figure) move in different directions, like in examples (22) and (23) where only the patient is 'packed in' or 'taken out', Japanese cannot express deictic direction any longer, or if it does, the meaning of the clause is changed.

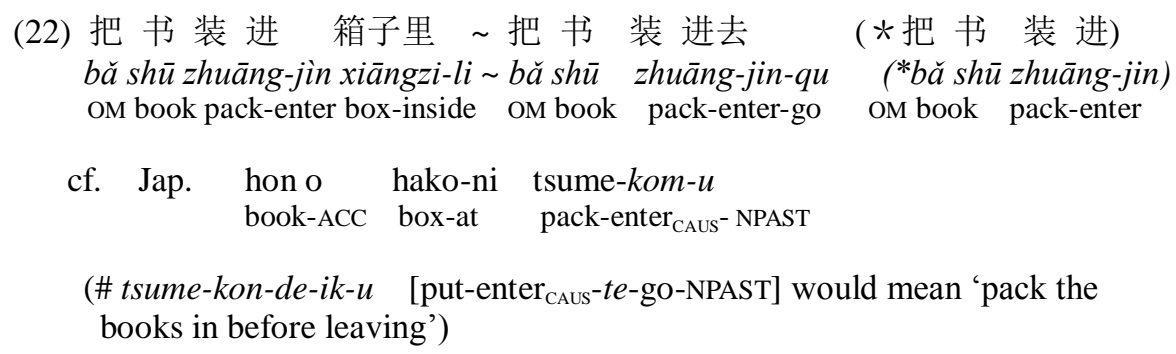




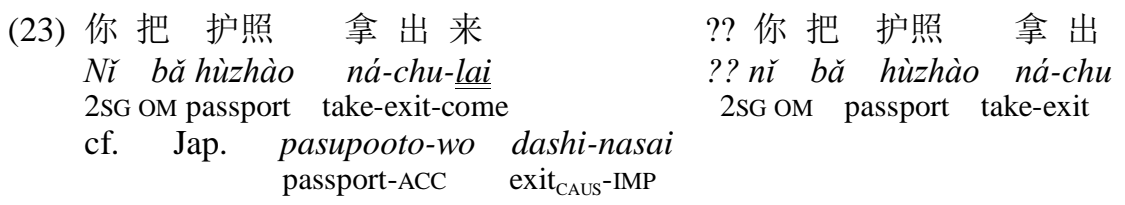

(\# dashitekinasai [exit ${ }_{\mathrm{CAUs}}$-te-come-IMP] would require the owner to go and fetch the passport, take it out, then come back)

In short, the Chinese sentence is not felicitous without the deictic element -lai if not followed by the ground NP or the Figure NP, whereas the Japanese translation would have to delete this deictic element. In the situation illustrated by (23), the subject of the sentence is ordered by a policeman to take out (from the pocket of her bag) her passport. The Japanese complex predicate with -ki-nasai 'come' will be accepted only in another situation, for instance if the owner of the passport moves to another room to remove her passport from a suitcase, and then comes back. Example (24) is taken from the Chinese novel Rickshaw (by Lao She). Japanese deletes the original deictic information, and translates the motion with its causative path verbs dasu and ireru (corresponding to the non-causative verbs deru and hairu). Interestingly, French and English translations delete this deictic information too:

(24) [Ch.] 他 把 车 拉出去 又 拉进来了,......[Rickshaw chap. 1]

tā bă chē lā-chu-qu yòu lā-jin-laile 3s OM rickshaw pull-exit-go again pull-enter-come PFV

[Jap.] Kare-wa kuruma-wo dashi-tari ire-tari... 3S-TOP rickshaw-ACC exit CAUS $^{-A L T} \quad$ enter $_{\text {CAUS }}$-ALT

[Fr.] Il sortit le pousse du garage et le rentra.

[Eng.] ... he pulled the rickshaw back and forth through the gateway...

Example (25) is taken from a compendium of Chinese directional complements providing Japanese translations (Hou et al. 2001). Needless to say that these 'complements' are troublesome for Japanese learners of Chinese. Japanese kaesu is the causative form of kaeru 'return'.

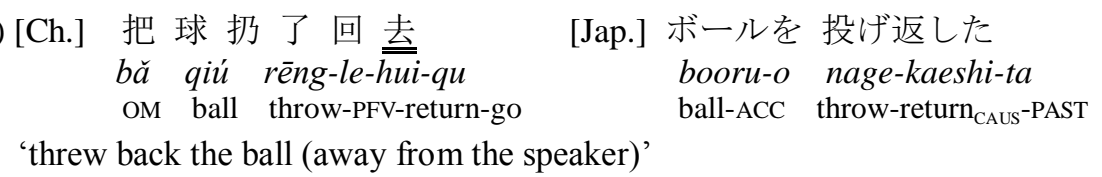

\subsection{Specific uses of deictic motion verbs in Japanese linked to subjectification}

In the precedent section, we emphasized the pervasive use of deictic directionals in Chinese caused motion clauses, whereas Japanese has to delete this information. However, Japanese does express deictic motion in cases where Chinese does not. This section presents two linguistic patterns in which the tendency to express any motion as being related to the location of the agent triggers some verbal compounds with a sequential reading [do something and then go/come] into developing a derived meaning: many activities of everyday life will be expressed as related to the deictic motion of the agent. For instance, someone leaving work in the evening will suggest her colleagues to have a drink 'on their way home', that is 'to drink and then go' non-de-ik-u [drink-te-go-NPAST]. The closest Chinese equivalent would be sentences like 吃了饭再走 chī-le fàn zài zǒu [eat-PFV rice and.only.then leave] 'eat something before you leave', i.e. a complex sentence including a conjunction to link the sequential actions. In most of the cases, however, the Chinese sentence used in equivalent situations will not involve any expression of motion. We refer the reader to Uehara 2006 for a detailed discussion on deixis and subjectivity in Japanese.

Another case of grammaticalization (and subjectification) of deictic motion verbs is the use of verbs followed by -kuru 'come' to express that the action denoted by the first predicate directly affects the speaker (or someone he/she has empathy with). Such use is restricted to the venitive deictic verb. Shibatani (2003) calls it an 'inverse marker', 
and links it to voice phenomena. In this case, -kuru is not interpreted as a sequential motion even when it appears after causative motion verbs like 'throw the ball' booru o nageru. In the following example (26a), borrowed from Shibatani (2003), nageru 'throw' and kuru 'come' combine to express the deictic direction of the ball (patient), apparently just as in Chinese (26b):

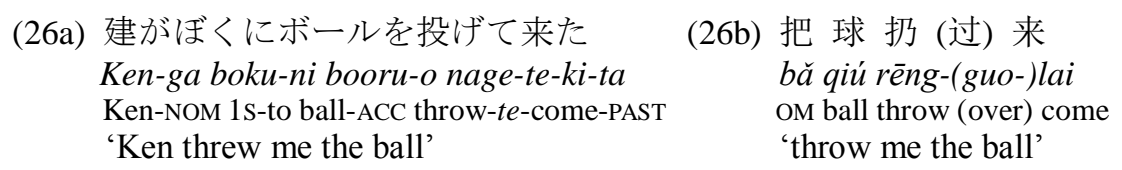

However, such constructions can be accounted for as an extension of the spatial deictic direction, to express affectedness. This explains why they lack a corresponding pattern with the andative verb (example 27a is also taken from Shibatani 2003). Subjectivity can only be expressed by the deictic center 'I':

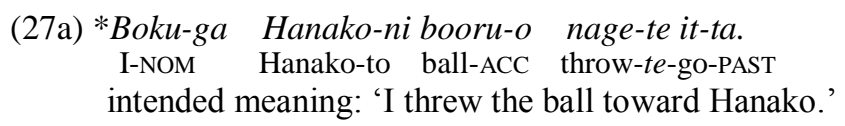

In Chinese, on the opposite, the andative directionals -qu can combine with 'throw' to express that the ball is sent away from the deictic center', as in (26b): the similarity of (26a) and (26b) was deceitful.

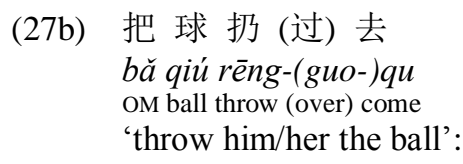

\section{Chinese expresses deictic direction more often than French or English}

French, like other Romance languages, is known for its pervasive use of personal pronouns, and this widespread use of personal deixis is probably one factor allowing it to deal so loosely with spatial deixis. As we showed in Section 3, one of the factors explaining the pervasive expression of deictic direction in Chinese is the lexicalization pattern of path verbs and path satellites: path verbs are most of the time bimorphemic, and deictic direction gets readily expressed in sentences where nondeictic path is marked. We showed that this tendency was stronger in some syntactic configurations (when no postverbal NP appears in the clause). The following sentences are taken from the famous Chinese novel Rickshaw (1937) and its French and English translations. Let us look first at causative motion events including the nondeictic path satellite 'exit' -chu. Neither French nor English expresses the direction 'toward the speaker' as Chinese does when someone takes out something from one's pocket or a bag etc. English translates the co-event verb as 'take out', French as sortir 'take out'.

(28) 祥子 没去 端 碗, 先 把 钱 掏了出 来: .... (chap. 4) Xiángzi méi qù duān wăn, xiān bă qián tāo-le-chu-lai...

Xiangzi NEG go hold bowl first oM money pull-PFv-exit-come

[Fr.] Avant de toucher à la nourriture, Siang-tse sortit une liasse de billets ...

[Eng.] Hsiang Tsu did not take the rice bowl. He took out his money instead.

Similar examples can be seen throughout the novel. This tendency is not limited to clauses that include a co-event verb, and indeed holds in cases where the nondeictic path element functions as the main verb too. Example (28) includes two tokens, one in the narrative, and the other in a dialogue part. In the former, the viewpoint is that of the hero (Xiangzi). English, thanks to its combination of deictic motion verbs and verb particles expressing nondeictic path, has no trouble in translating it as go/come in. French, on the other hand, can only choose between deictic and nondeictic motion, and regularly chooses the latter entrer/sortir 'enter/exit' throughout the novel: 
(29) 他决定进去见她 $[\ldots]$ 大着胆 叫了 声 刘姑娘。

tājuéding jìn-qu jiàn tā [...] dà-zhe dăn jiào-le shēng Liú-gūniang

3SG decide enter-go see 3SG big-DUR guts call-PFV CL Liu-miss

— “进来!” [Rickshaw, Chapter 6]

Jin-lai

enter-come

[Fr.] ... il se decida à entrer chez Tigresse,... [...] il appela : — Mademoiselle Tigresse ! — Entre.

[Eng.]...until he decided to go in and see her. [...] and then very bravely called her name. "Come in!"

Our last example illustrates the way Chinese adds deictic information in translations from English, another S-language. It is taken from Harry Potter (vol. 2 The Chamber of Secrets). Note that in this case it would be difficult for English to translate the Chinese text without omitting the deictic information.

(30) ... and Aunt Petunia's hand appeared, pushing a bowl of canned soup into the room. [The Chamber of Secrets, Chapter 2, p. 22)
[Ch.] 从 洞口 cóng dòngkóu
from hole
推进来一碗罐头汤。
tuī-jin-lai yì wăn guàntóu tāng
push-enter-come one bowl canned soup
[Fr.].... poussant à l'intérieur de la chambre un bol rempli de soupe en boîte.

These examples, together those given in Section 4, show that the overt expression of deictic direction is to some extent constrained by various language-specific factors.

\section{Conclusion and perspectives for further research}

Our analysis of Chinese and Japanese data confirmed Talmy's and Slobin's remarks based on other languages: the way a language encodes deictic path cannot be totally predicted by the way it encodes nondeictic path. However, we suggest that this slightly disappointing statement should be, to some extent, offset by the following observations:

1) The encoding of deictic motion is not totally free of the constraints brought on by the typological features of the language as an S-language or a V-language. Talmy (2000:213-288) provided various cross-linguistic evidence to show that in an S-language, satellites function to express change of state as well. We argue that the V-language characteristics of Japanese blocked the marking of deictic viewpoint in caused motion events, and favored the semantic extension of venitive directionals into 'subjectivity markers' expressing affectedness (Section 4). Chinese path satellites, on the other hand, function in many ways like the postverbal devices used to express change of state and causation in non-motion events (often called 'resultative complements'). The discrepancy between Chinese and Japanese observed here for causative motion contrasts with their similarity in encoding autonomous motion, and is adequately accounted for by Talmy's framework.

2) On the other hand, deictic path is special: whatever the language, its special link to the linguistic expression of subjectivity motivates its different categorization. Languages which assign spatial deixis an important role in the expression of subjectivity will thus often find a way to express both types of paths, nondeictic and deictic, in the same clause. Chinese and Japanese have been characterized as being 'lococentric' (Paris 1992, Rygaloff 1977). Paris $(1992,1997)$ noted that in Chinese spatial deixis was prevalent in the deictic triad ' $\mathrm{I} / \mathrm{now} / \mathrm{here}$ ', person being secondary ${ }^{11}$. This factor obviously works at a very different level in a language from the more clearly syntactic factors related to causation and change-of-state, and we should be aware that both types of mechanisms are likely to influence the way deictic path gets categorized in a language. Some languages like French or Russian show a very low amount of interest in the linguistic expression of deictic direction, in spite of their belonging to different types

\footnotetext{
11 «[Le] chinois traite la personne comme un lieu (+ humain): personne et lieu sont co-extensifs. » (Paris 1992 :174)
} 
(French is a V-language, Russian an S-language).

We will end this short study by a last observation and suggest some directions for further research. We focused quite narrowly on Standard Mandarin deictic directionals -lai and - $q u$, and we saw that some Chinese dialects have developed a highly constrained bipartite category of path satellites: the overt expression of nondeictic path very often entails the expression of deictic direction as well. Although cross-linguistic data (Russian, Hungarian for S-languages, Japanese and Korean for V-languages) prove that this bipartite expression of paths cannot be explained merely as the result of the typological change Chinese underwent in moving from a V-language to an S-language, we still believe that in the case of Chinese the assignment of nondeictic and deictic direction to separate slots has something to do with the development of directional satellites (directional complements). Although this claim definitely needs to be substantiated, our opinion is that the bipartite nature of Chinese directionals results from a compromise between their semantics and their syntactic position. Semantically, a deictic directional is not necessarily 'bounding', especially the andative item -qu. By combining with more bounding elements (nondeictic path satellites), deictic directionals are somehow 'freed' from the syntactic tasks of satellites, and allowed to play a less constrained role.

\section{References for Corpora}

- Luótuo xiángzi, by Lao She (Le pousse-pousse, tr. by F. Cheng \& A. Cheng, Picquier, 1990; Rickshaw, tr. by J. M. James, U. of Hawaii Press, 1979; Rakuda Shooji, tr. by T. Nakayama, Hakuteisha, 1991.) Abbreviated as [Rickshaw].

- Rén dào zhōngnián [At middle age] by Chen Rong: 《人到中年》(First published in 1980)

- Harry Potter: The Chamber of Secrets. (By J.K. Rowlings, 2000, Bloomsbury).French tr.: J.F. Ménard, (Gallimard Jeunesse 2000), Chinese tr.: Mă Àixīn (Hālì Pōtè yǔ mishì , Renmin Wenxue Chubanshe, 2000). Abbreviated as [Middle age].

-Shishuoxinyu: translated by Wang Jianshe, Shehui Kexue Chubanshe 2004 《《世说新语》选译新注》北京:社会科学文献出 版社、王建设 译注 2004

- Strange tales of Liaozhai : "Nie Xiaoqian" (book 1), "A laughing girl named Yingning" (book 2), and "A girl called Rouge" (book 10). The modern Chinese translation used here was published in Taipei, Guojia Chubanshe, translation by He Changren, in 2004: 《聊齋誌異〔白話本〕》蒲松齡著, 臺北：國家出版社 2004, 何昌仁譯

- Jiéhūn shí nián [Married ten years] (VCD, directed by Gao Xixi, Beijing Dianshi Yishu Zhongxin Chubanshe). Abbreviated as [Ten years]. We are indebted to the $21^{\text {st }}$ cen. COE project 'Evolutionary Cognitive Sciences in Komaba' (the University of Tokyo), which funded data-gathering and coding for a database using Chinese TV drama series.

\section{List of the abbreviations used in the glosses}

1SG, 2PL etc.: 1rst person singular, $2^{\text {nd }}$ person plural; ACH: achievement marker; ACC: accusative marker; AGT: agentivity marker ; ALT: alternative form (Jap., marks alternating events); BEN: preposition marking benefactive; CL: classifier; DUR: Ch. durative suffix -zhe; GEN: genitive marker; IMP: imperative form; NOM: nominative marker (Jap.); NPAST: nonpast; OM: Ch. object marker bă; PAST: past; PFV: perfective suffix -le and sentence particle le which marks a change of state; PRE: present tense; PRT: sentence-final particle; SIM: adverb marking two simultaneous actions ; TOP: topic marker; $\mathrm{VERB}_{\mathrm{CAus}}$ : (Jap.) the causative form of the verb.

\section{List of the abbreviations used in the text (by order of apparition)}

S-language: satellite-framed language; V-language: verb-framed language, PPs : Prepositional Phrases; NP: Noun Phrase; $P_{d}$ : deictic path; $\mathrm{P}_{\mathrm{nd}}$ : nondeictic path; $\mathrm{V}_{\text {co-e }}$ : co-event Verb; $\mathrm{NP}_{\mathrm{FIG}}$ : the Figure NP, i.e. the noun phrase expressing the moving entity; $\mathrm{NP}_{\mathrm{LOC}}$ : Locative or Ground NP; Ch.: Chinese; Fr. : French; Jap. : Japanese.

\section{Bibliography}

[Arakawa, K.] 荒川 清秀 (1994). 「買ッテクルと “买来”」 Kattekuru to măilai [Kattekuru and măilai ], 『愛知大学外 国語研究紀要』Aichi Daigaku Gaikokugo Kenkyuu Kiyoo, 18, 71-81.

Berthele, R. (2004). The typology of motion and posture verbs: a variationist account. In B. Kortmann (ed.), Dialectology meets Typology: Dialect Grammar from a Cross- Linguistic Perspective (93-126). Berlin: Walter de Gruyter.

Chao, Y. R. (1968). A Grammar of Spoken Chinese, Berkeley: University of California Press. 
Craig, C. (1993). Jakaltek directionals: their meaning and discourse function. Languages of the World, 2, 23-36. (Lincom Europa).

[Cūi, D.] 崔 达送 (2005). 《中古汉语位移动词研究》Zhōnggǔ Hănyǔ wèiyí dòngcí yánjiū [Studies on Medieval Chinese motion verbs]. 合肥 Hefei: 安徽大学出版社 Anhui University Press.

Fillmore, C. (1997). Lectures on Deixis. Stanford University: CSLI Publications.

François, A. (2003). Of Men, Hills, and Winds: Space Directionals in Mwotlap, Oceanic Linguistics, 42-2, 407-437.

[Fukami, K.] 深見 兼孝 (1999). 日本語の “ていく・てくる”と朝鮮語の a/ə gada・a/ə oda」 Nihongo no teiru/tekuru to Choosengo no a/gada-a/oda [Japanese teiku-teiru and Korean a/gada-a/ oda], 『広島大学教育学部紀要』Hiroshima Daigaku Kyooikugakubu Kiyoo, [Bulletin of the Faculty of Education, Hiroshima University]. Part 2, Vol. 38, 47-52.

[Hóu, J.] 侯 精一 et al. (2001). 《中国語補語例釈 日文版》Zhōngguóyǔ bǔyǔ lìshì - Rìwénbăn. [A compendium of Chinese complements: Japanese edition]. 北京 Beijing: 商务印书馆 Commercial Press.

Hyslop, C. (2001). The Lolovoli dialect of the North-East Ambae Language, Vanuatu. Pacific Linguistics 515. Camberra: The Australian National University.

[Jū, H.] 居 红 (1992). 《汉语趋向动词及动趋短语的语义和语法特点》Hànyǔ qūxiàng dòngcí jí dòngqū duănyǔ de yǔyì hé yǔfã tèdiăn [Semantic and Syntactic Characteristics of Chinese Directional Verbs and Verb Phrases], 《世界汉语教学》Shìjiè Hànyŭ Jiàoxué [Chinese Teaching in the World], 4, 276-282.

Koga, T., Koloskova Y. et al. (2006). The linguistic encoding of motion events in English, Russian and German - a contrastive study with Japanese - Paper read at the $132^{\text {nd }}$ meeting of the Linguistic Society of Japan, the University of Tokyo (17-18 July 2006).

Kopecka, A. (2006). The semantic structure of motion verbs in French : typological perspectives. In M. Hickmann and S. Robert (eds.), Space in Languages: Linguistic Systems and Cognitive Categories (pp. 83-101). Amsterdam/Philadelphia: John Benjamins.

[Lamarre C.] 柯理思 (2002). 《汉语方言里连接趋向成分的形式》 Hànyǔ fāngyánli liánjiē qūxiàng chéngfèn de xíngshì [An Investigation of the various markers inserted between verbs and directionals in Han dialects], 《中国语文研究》Zhōngguó Yǔwén Yánjiū [Studies in Chinese Linguistics] 1, 26-44. (Hong Kong)

[Lamarre, C.] 柯理思 (2003). 汉语空间位移事件的语言表达 - 兼论述趋式的几个问题 Hànyǔ Kōngjiān wèiyí shìjiàn de yǔyán biăodá [The linguistic encoding of motion events in Chinese], 《现代中国语研》 Xiàndài Zhōngguóyǔ Yánjiū [Contemporary Research in Modern Chinese], 5, 1-18 (Kyoto).

[Lamarre, C.] 柯 理思 (2005). 《讨论一个非典型的述趋式: “走去”类组合》 Tăolùn yí ge fēi diănxíng de shùqūshì: 'zǒuqù' lèi zŭhé [On a non-prototypical Verb-Directional construction: zŏuqù and similar compounds]. In J. Shěn, Wú and Hóng (eds.), 《语法化与语法研究(二)》(pp. 53-68), 商务印书馆.

Lamarre, C. (2006). 《动词后置成分 “走” 的语法化》 Dòngcí hòuzhì chéngfèn zǒu de yŭfăhuà [The grammaticalization of postverbal directional -zou 'away']. In N. Ogoshi (ed.), Contrastive Studies of Grammaticalization and Categorization in East Asian Languages - from particulars to universals, Project Report for Grant-in aid for scientific research n. 14310221 (2002-05), pp. 104-116. University of Tokyo, Japan.

Lamarre, C. (2007). The Linguistic Encoding of Motion Events in Chinese: With Reference to Cross-dialectal Variation. In C. Lamarre and T. Ohori (eds.), Typological Studies of the Linguistic Expression of Motion Events, Volume 1: Perspectives from East and Southeast Asia (pp. 3-33). Tokyo: Center for Evolutionary Cognitive Sciences at the University of Tokyo (21 ${ }^{\text {st }}$ century COE Program).

Lamarre, C. (2007b). 《试探北方官话的指示位移动词与 “上/到+处所词+来/去” 格式》Shìtàn Běifāng Guānhuà de zhřshì wèiyí dòngcí yŭ "shàng/dào + chùsuǒcí + lai/qu” géshì [Northern Chinese synthetic and analytic deictic motion verbs]. Paper read at the $4^{\text {th }}$ Conference on Mandarin Dialects, Ankang (Shaanxi), Oct. 2007.

[Lamarre, C. \& Liu, S.] 柯 理思、刘 淑学. (2001). 《河北冀州方言 “拿不了走”一类的格式》 Héběi Jìzhōu fângyán nábuliǎozǒu yílèi de géshì [Patterns like nábuliǎozǒu in the Jizhou dialect of Hebei], 《中国语文》Zhōngguó Yǔwén, 5, 428-438.

[Liu, D.] 劉 丹青 (2000). 《粵語句法的類型學特點》(Yuèyǔ jùfã de lèixíngxué tèdiăn) [The typological characteristics of Cantonese Syntax], 《亞太語文教育學報》(Yà-Tài yǔwén jiàoyù Xuébào) [Asia Pacific Journal of Language in Education], 3-2: 1-29 (Hong Kong).

[Liu, Y. (ed.)] 刘月华 主编 (1998). 《趋向补语通释》Qūxiàng bǔyǔ tōngshì [Directional complements: a compendium]. 北 京 Beijing: 北京语言文化大学出版社 Běijīng Yǔyán Wénhuà Dàxué.

Matsumoto, Y. (1996). Complex Predicates in Japanese: A Syntactic and Semantic Study of the Notion 'Word'. Stanford: CSLI Publications and Tokyo: Kurosio Publishers.

Matsumoto, Y. (2003). Typologies of lexicalization patterns and event integration: Clarifications and reformulations. In S. Chiba et al. (eds.), Empirical and Theoretical Investigations into Language: A Festschrift for Masaru Kajita (pp. 403-418). Tokyo: Kaitakusha. 
Paris, M.-C. (1992). Démonstratifs et personne en chinois standard. In M-A. Morel and L. Danon-Boileau (eds.), La deixis (pp. 166-175). Paris: Presses Universitaires de France.

Paris, M.-C. (1997). L'espace énonciatif en chinois moderne: mais où la triade est-elle passée? In C. Fuchs and S. Robert (eds.), Diversité des langues et représentations cognitives (pp. 93-105). Ophrys. (English translation : John Benjamins 1999)

Peyraube, Alain. 2006. Motion Events in Chinese: A diachronic study of directional complements. In Hickmann and Robert (eds.), Space in Languages: Linguistic Systems and Cognitive Categories (pp. 121-135). Amsterdam/Philadelphia: John Benjamins.

[Qi, H.] 齐沪扬. (1998). 《现代汉语空间问题研究》 Xiàndài Hànyǔ kōngjiān wèntí yánjiū [Studies on spatial issues in Modern Chinese], 上海 Shanghai : 学林出版社 Xuélín Chūbănshè.

Ross, M. (2004). The Grammaticization of directional verbs in Oceanic languages. In I. Bril and F. Ozanne-Rivierre (eds.), Complex Predicates in Oceanic Languages --- Studies in the Dynamics of Binding and Boundness (pp. 297-329). Berlin: Mouton de Gruyter.

Rygaloff, A. (1977). Existence, possession, présence (être et avoir), Cahiers de Linguistique Asie Orientale, 1, 7-16.

Shibatani, M. (2003). Directional Verbs in Japanese. In E. Shay \& U. Seibert (eds.), Motion, direction and location in languages (pp. 258-86). Amsterdam: John Benjamins.

Slobin, D. (1997). The Universal, the Typological, and the Particular in Acquisition. In D. Slobin (ed.) The Crosslinguistic Study of Language Acquisition. Vol. 5: Expanding the Contexts (pp. 1-39). Mahwah/London: Lawrence Erlbaum.

Slobin, D. (2004). The many ways to search for a frog: Linguistic typology and the expression of motion events. In Strömqvist \& Verhoeven (eds.) Relating events in narrative: Vol. 2. Typological and contextual perspectives (pp. 219-257). London: Lawrence Erlbaum.

Talmy, L. (1985). Lexicalization patterns: Semantic structure in lexical form. In T. Shopen (ed.) Language typology and syntactic description, vol. III: Grammatical categories and the lexicon (pp. 57-149). Cambridge: Cambridge University Press.

Talmy, L. (2000). Toward a Cognitive Semantics - Vol. II : Typology and process in Concept Structuring. Cambridge (Ma) : MIT Press.

Tanaka, S. \& Matsumoto, Y. (1997).『空間と移動の表現』 Kuukan to Idoo no Hyoogen [Linguistic Expressions of Space and Motion]. 東京 Tokyo: 研究社 Kenkyusha.

Tang, Zhengda. \& Lamarre, C. (2007). A contrastive study of the linguistic encoding of motion events in Standard Chinese and in the Guanzhong dialect of Mandarin (Shaanxi), Bulletin of Chinese Linguistics, 2.1.

Xu, Dan. (2006). Typological change in Chinese Syntax. Oxford: Oxford University Press.

Uehara, S. (2006). Toward a typology of linguistic subjectivity: A cognitive and cross- linguistic approach to grammaticalized deixis. In A. Athanasiadou et al. (eds.), Subjectification: Various paths to subjectivity (pp. 75-117). Berlin: Mouton de Gruyter.

Wilkins, D., \& Hill, D. (1995). When "go" means "come": Questioning the basicness of basic motion verbs. Cognitive Linguistics, 6-2/3, 209-259. 